\section{Sources of Resistance to Two-spotted Spider Mite (Acari: Tetranychidae) in Citrullus spp.}

\author{
Rolando López \\ Clemson University, Costal Research and Education Center 2700 Savannah \\ Highway, Charleston, SC 29414
}

\begin{abstract}
Amnon Levi ${ }^{1}$
U.S. Department of Agriculture, Agricultural Research Service, U.S. Vegetable Laboratory, 2700 Savannah Highway, Charleston, SC 29414
\end{abstract}

\author{
B. Merle Shepard \\ Clemson University, Costal Research and Education Center 2700 Savannah \\ Highway, Charleston, SC 29414
}

\begin{abstract}
Alvin M. Simmons and D. Michael Jackson
U.S. Department of Agriculture, Agricultural Research Service, U. S. Vegetable Laboratory, 2700 Savannah Highway, Charleston, SC 29414
\end{abstract}

Additional index words. plant resistance, watermelon, breeding, germplasm, Tetranychus urticae, mite resistance

\begin{abstract}
The two-spotted spider mite, Tetranychus urticae Koch (Acari: Tetranychidae), often causes serious damage to watermelon (Citrullus spp.), and there is a need to evaluate and identify watermelon germplasm resistant to $T$. urticae. Watermelon cultivars (Citrullus lanatus var. lanatus), and U.S. plant introduction (PI) accessions of $C$. lanatus var. citroides and $C$. colocynthis, were evaluated for preference by $T$. urticae (number of adults and eggs on leaves). In open-choice experiments in the greenhouse and in laboratory rearing cages, there was a significant preference by $\boldsymbol{T}$. urticae for watermelon cultivars, Citrullus lanatus var. lanatus PIs, and $C$. lanatus var. citroides PIs over $C$. colocynthis PIs. All watermelon cultivars and PIs were infested, but the $C$. colocynthis PIs were significantly less infested with T. urticae. The $C$. colocynthis PIs may be useful sources for enhancing $T$. urticae resistance in cultivated watermelon.
\end{abstract}

Watermelon (Citrullus lanatus var. lanatus) is a major vegetable crop in the U.S., with total annual production of $2.2 \times 10^{6} \mathrm{t}$, and a farm value of $\$ 340$ million (USDA Agricultural Statistics Service, 2004). The largest production areas are in Texas, Florida, California, Georgia, Indiana, and Arizona (National Watermelon Promotion Board, 2004). Watermelon accounts for about $2 \%$ of world acreage devoted to vegetable production (Food and Agricultural Organization, 1995). Experiments with isozyme (Navot and Zamir, 1987) and DNA markers (Levi et al., 2001a, 2001b) indicated that cultivated watermelon has a narrow genetic base. As a result, watermelon cultivars are susceptible to numerous diseases and pests. The U.S. plant introduction (PI) collection (www.ars-grin. gov) includes Citrullus species and subspecies collected in different parts of the world and with a wide genetic diversity (Levi et al., 2001a, 2001b). Some of these PIs may contain resistance to watermelon pests as reported

Received for publication 24 Jan. 2005. Accepted for publication 5 Apr. 2005. Mention of a trademark, proprietary product, or vendor does not constitute a guarantee or warranty of the product by the U.S. Dept. of Agriculture and does not imply its approval to the exclusion of other products or vendors that also may be suitable.

${ }^{1}$ Corresponding author; e-mail alevi@saa.ars. usda.gov. for whiteflies (Simmons and Levi, 2002) and nematodes (Thies and Levi, 2004).

Citrullus Schrad. ex Eckl. \& Zeyh. is a major genus of Cucurbitaceae. It comprises four known diploid species: 1) C. lanatus (Thunb.) Matsum \& Nakai, found in tropical and subtropical climates worldwide and includes the cultivated watermelon (C. lanatus var. lanatus) and the preserved melon (C. lanatus var. citroides) (Whitaker and Davis, 1962; Whitaker and Bemis, 1976); 2) the perennial bitter gourd, $C$. colocynthis (L.) Schard, that grows in sandy areas throughout North Africa, Southwestern Asia, and the Mediterranean (Burkill, 1985; Jarret et al., 1997; Navot and Zamir, 1987; Zamir et al., 1984; ); 3) the perennial species C. ecirrhosus Cogn. (Meeuse, 1962); and 4) the annual species C. rehmii De Winter (De Winter, 1990). Both C. ecirrhosus and C. rehmii are endemic to the desert regions of Namibia (Meeuse, 1962).

The two-spotted spider mite (TSSM), Tetranychus urticae Koch (Acari: Tetranychidae), attacks a wide range of horticultural crops (Huffaker et al., 1969, 1970; McMurtry et al., 1970; van de Vrie et al., 1972) including watermelon in the greenhouse as well as in the field (Capinera, 2001; Jeppson et al., 1975). TSSM can inflict severe damage to watermelon plants, particularly during fruit setting and development by causing plant senescence and death in severe cases, before full fruit maturation, and yield losses with milder infestations.

Acaricides are the primary control tactic for TSSM. However, TSSM resistance to a wide range of insecticides is documented throughout the world (Hassan and Oomen, 1985). Many of the acaricides that target TSSM also kill beneficial parasitoids and predators (Lazarre and Gerling, 1993; Simmons and Jackson, 2000). As a result, TSSM infestations in watermelon fields often become uncontrollable (Capinera, 2001; Watson, 1964). Therefore, there is a need to develop watermelon varieties with improved TSSM resistance. This resistance, combined with the use of indigenous and natural enemies could form the basis of a sustainable integrated pest management (IPM) program for watermelon. Hence, there is a need to thoroughly evaluate the Citrullus germplasm and identify potential sources of TSSM resistance that can be exploited for the improvement of commercial watermelon.

The Citrullus collection at the USDA-ARS, Plant Genetic Resources and Conservation Unit, Griffin, Ga., includes >1,600 U.S. PIs. Of these, 1,480 PIs are C. lanatus var. lanatus, 110 PIs are C. lanatus var. citroides, and 24 PIs are $C$. colocynthis [Germplasm Resources Information Network (GRIN), Online Database, National Germplasm Resources Laboratory, Beltsville, Md.; www.ars-grin.gov]. Most $C$. colocynthis PIs were resistant to whiteflies (Simmons and Levi 2002). Moreover, in our preliminary observations in the greenhouse, we noticed that $C$. colocynthis plants were not preferred by TSSM compared with other Citrullus PIs and watermelon cultivars. We know of no published studies of the resistance of Citrullus species to TSSM.

The objective of this study was to evaluate selected U.S. PIs of C. lanatus var. lanatus, $C$. lanatus var. citroides, and C. colocynthis, and identify PIs that might be potential sources of resistance for TSSM in watermelon.

\section{Materials and Methods}

Plant material. Five watermelon cultivars, three $C$. lanatus var. lanatus PIs, eight $C$. lanatus var. citroides PIs, and twenty-two $C$. colocynthis PIs (Table 1) were evaluated for resistance to TSSM in a greenhouse and a rearing room, at the USDA-ARS, U.S. Vegetable Laboratory, Charleston, S.C. Seeds of all PIs were obtained from the USDA-ARS, Plant Genetic Resources Conservation Unit(Griffin). Six plants of each watermelon cultivar and U.S. PI were grown in 1-gal pots containing Jiffy Mix. Plants were grown in a greenhouse with day and night temperatures of 28 and $21^{\circ} \mathrm{C}$, respectively, and with a light intensity of 450 lux at leaf sample height (as measured with a LI-185B photometer; LI-COR, Lincoln, Nebr.), and light/dark periods of about $16 / 8 \mathrm{~h}$.

Source of spider mites. During the winter of 2003-04, TSSMs were collected from fieldgrown strawberry (Fragaria $\times$ ananassa Duchesne) plants. The TSSMs were then multiplied on pinto bean (Phaseolus vulgaris L.) plants grown on trays in a rearing cage.

Free-choice bioassayin greenhouse. Assays 
Table 1. Mean number of two-spotted spider mites (TSSMs) on the 4th leaf of watermelon cultivars or U.S. plant introductions (PIs) of Citrullus lanatus var. lanatus (L), Citrullus lanatus var. citroides (C), and Citrullus colocynthis $(\mathrm{O})$, after 5 weeks in a greenhouse infested with TSSMs.

\begin{tabular}{lcrr}
\hline Entry & $\begin{array}{c}\text { Citrullus } \\
\text { group }\end{array}$ & $\begin{array}{c}\text { Adults } \\
\text { and nymphs }^{2}\end{array}$ & Eggs $^{\mathbf{2}}$ \\
\hline PI 596666, PI 596669, PI 500331, PI 500354, PI 532738 & $\mathrm{C}$ & $>150 \mathrm{a}$ & $>180 \mathrm{a}$ \\
Florida Giant, Minilee, Dixilee, & $\mathrm{L}$ & $>150 \mathrm{a}$ & $>180 \mathrm{a}$ \\
PI 271778, PI 518611, PI 560901, PI 505604 & $\mathrm{L}$ & $>150 \mathrm{a}$ & $>180 \mathrm{a}$ \\
Charleston Gray & $\mathrm{L}$ & $79 \mathrm{~b}$ & $273 \mathrm{a}$ \\
Crimson Sweet & $\mathrm{L}$ & $40 \mathrm{c}$ & $64 \mathrm{c}$ \\
PI 542123, PI 244018 & $\mathrm{C}$ & $31 \mathrm{c}$ & $62 \mathrm{c}$ \\
PI 482283 & $\mathrm{O}$ & $12 \mathrm{~d}$ & $25 \mathrm{~d}$ \\
PI 386024, PI 269365 & $\mathrm{O}$ & $1 \mathrm{e}$ & $2 \mathrm{e}$ \\
PI 386014, PI 296341, PI 299378, PI 374216, PI 386015 & $\mathrm{O}$ & $0.1 \mathrm{f}$ & $0.1 \mathrm{f}$ \\
PI 386016, PI 386018, PI 386019, PI 386025, PI 386026 & $\mathrm{O}$ & $0.1 \mathrm{f}$ & $0.1 \mathrm{f}$ \\
PI 388770, PI 432337, PI 482311, PI 525082, PI 537277 & $\mathrm{O}$ & $0.1 \mathrm{f}$ & $0.1 \mathrm{f}$ \\
PI 542616, PI 549161, PI 596676, PI 596677 & $\mathrm{O}$ & $0.1 \mathrm{f}$ & $0.1 \mathrm{f}$ \\
Griffin 142001, Griffin 142002 & $\mathrm{O}$ & $0.1 \mathrm{f}$ & $0.1 \mathrm{f}$ \\
\hline
\end{tabular}

${ }^{2}$ Means in a column with different letters are significantly different $(P<0.05)$ according to Duncan's multiple range test.

Table 2. Mean number of two-spotted spider mites (TSSMs) on the detached fourth leaf of a watermelon cultivar and Citrullus colocynthis plant introductions (PIs) after 1 week of limited free-choice bioassay with single leaves in a closed container.

\begin{tabular}{lcc}
\hline Entry & $\begin{array}{c}\text { Adults and } \\
\text { nymphs }\end{array}$ & Eggs \\
\hline Crimson Sweet & $3.98 \mathrm{a}^{\mathrm{z}}$ & $3.74 \mathrm{a}$ \\
PI 386015 & $1.13 \mathrm{~b}$ & $0.35 \mathrm{~b}$ \\
PI 386018 & $0.98 \mathrm{~b}$ & $0.44 \mathrm{~b}$ \\
PI 386024 & $0.80 \mathrm{~b}$ & $0.20 \mathrm{~b}$ \\
PI 346082 & $1.32 \mathrm{~b}$ & $0.32 \mathrm{~b}$ \\
\hline
\end{tabular}

${ }^{\mathrm{z}}$ Means in a column with different letters are significantly different $(P<0.05)$ according to Duncan's multiple range test.

Table 3. Mean number of two-spotted spider mites (TSSMs) on a leaf of a watermelon cultivar and Citrullus colocynthis plant introductions (PIs) after 1 week of free-choice bioassay in a closed rearing cage.

\begin{tabular}{lcc}
\hline Entry & $\begin{array}{c}\text { Adults and } \\
\text { nymphs }\end{array}$ & Eggs \\
\hline Crimson Sweet & $3.2 \mathrm{a}^{\mathrm{z}}$ & $7.3 \mathrm{a}$ \\
PI 386015 & $0.9 \mathrm{~b}$ & $1.6 \mathrm{~b}$ \\
PI 386018 & $0.4 \mathrm{~b}$ & $0.5 \mathrm{~b}$ \\
PI 386019 & $0.6 \mathrm{~b}$ & $0.7 \mathrm{~b}$ \\
PI 386024 & $0.4 \mathrm{~b}$ & $0.6 \mathrm{~b}$ \\
PI 386025 & $0.5 \mathrm{~b}$ & $0.6 \mathrm{~b}$ \\
\hline
\end{tabular}

${ }^{2}$ Means in a column with different letters are significantly different $(P<0.05)$ according to Duncan's multiple range test.

were conducted using 3-week-old Citrullus plants grown in the greenhouse. A free-choice greenhouse bioassay was conducted to evaluate preference of TSSMs to plants of PIs and cultivars. Six plants of each cultivar or PI(Table 1) were tested in a greenhouse infested with TSSMs. Two plants of each PI or cultivar were randomized on one of each of the three benches in the greenhouse $(1.3 \times 5 \mathrm{~m}$ each, and $1 \mathrm{~m}$ apart). One tray containing 24 TSSM-infested bean plants was placed on each bench in the greenhouse a day before placing the plants of Citrullus PI and watermelon cultivars on the bench. The plants were exposed to TSSMs for 5 week. A fully expanded true leaf from the fourth node from the apex of the vine was collected on the first and fourth week after placing the plants in the greenhouse. TSSM adults, nymphs, and eggs on each leaf were counted using a dissecting microscope.

Limited free-choice bioassay with single leaves in a closed container. A limited freechoice bioassay was conducted to assess preference of TSSM in a closed environment where C. colocynthis leaves were in close proximity with a leaf of a watermelon cultivar. The experiment was set in transparent cylindrical plastic jars $(12 \mathrm{~cm}$ diameter $\times 25 \mathrm{~cm}$ deep with a tight plastic lid). The jars were placed in a rearing room with light/dark periods of 14/10 $\mathrm{h}$, light intensity of 300 lux at leaf height, and a temperature of $26^{\circ} \mathrm{C}$. A leaf from the fourth node from the apex was detached from the vine of a 3-week-old plant of each of the four C. colocynthis PIs and from the watermelon cultivar Crimson Sweet (Table 2). Leaves were examined with a dissecting microscope to determine the presence of TSSM adults, nymphs and eggs. Following the examination, the leaf was placed in a 15 -mL floral wick (Syndicate Sales, Kokomo, Ind.) containing de-ionized water. Three floral wicks (two wicks, each containing a leaf of a different PI, and one wick containing a leaf of 'Crimson Sweet') were placed in a triangle formation $(8 \mathrm{~cm}$ apart) on a Styrofoam plate in the center of the jar. Using a small camel hair brush, three TSSM adults, one male and two females were carefully transferred to the bottom of each jar. the wicks and the number of TSSM adults and eggs were counted on each leaf. Five to seven assays (PI leaf versus 'Crimson Sweet' leaf in a closed container) were completed for each of the four C. colocynthis PIs (Table 2).

Free-choice bioassay with plants in a closed cage. A bioassay was conducted to test the infestation of TSSM on C. colocynthis compared with 'Crimson Sweet'. Five young plants (2- to 3-week-old in a 1-gal pot) of each of six C. colocynthis PIs and Crimson Sweet (Table 3) were used. Using a small camel hair paint brush, TSSM (three females and two males) were carefully collected from the bean plants and transferred to the surface of one leaf of each of the plants. Seven TSSM-infested plants (one from each of six PIs and one of 'Crimson Sweet') were placed in each of six plexiglass cages $(63.5 \times 63.5 \times 63.5 \mathrm{~cm})$. All After $4 \mathrm{~d}$, leaves were carefully removed from cages were kept in a rearing room and were individually ventilated. Light intensity over the cages was 350 lux, and light/dark periods of $14 / 10 \mathrm{~h}$. Temperature and relative humidity in the cage were $26^{\circ} \mathrm{C}$ and $80 \%$, respectively. Numbers of TSSM adults, nymphs, and eggs were counted for the fourth leaf from the apex of each plant at the end of the first week and observations continued for 4 weeks.

All data were analyzed with SAS (SAS Institute, 1994). Means were separated using the Duncan's multiple range test at $P<0.05$.

\section{Results and Discussion}

Among the three major Citrullus groups evaluated, PIs of C. colocynthis were the least preferred by TSSM for feeding, oviposition, and survival from egg to the adult stage. TSSM adults and eggs were observed on all plants of C. lanatus var. lanatus and C. lanatus var. citroides PIs, but lowest population density of TSSM were observed on the $C$. colocynthis PIs (Table 1). In all assays, TSSMs strongly preferred feeding and laying eggs on plants of Citrullus lanatus var. lanatus and Citrullus lanatus var. citroides compared to $C$. colocynthis (Tables 1, 2, and 3). Although limited free-choice bioassays were conducted, these were useful in demonstrating the strong preference of TSSM to C. lanatus var. lanatus over C. colocynthis. These bioassays showed that although most plants or leaves in each test were of $C$. colocynthis PIs, the TSSMs preferred the single plant or leaf of $C$. lanatus var. lanatus (Crimson Sweet) (Tables 2 and 3). Similarly, in a recent study examining preference of whiteflies to Citrullus PIs and watermelon cultivars, the $C$. colocynthis PIs were the least preferred by whiteflies for feeding and oviposition (Simmons and Levi, 2002). There was some variation among $C$. lanatus var. lanatus and C. lanatus var. citroides PIs and cultivar with respect to TSSM adult and egg density on leaves (Table 1). However, TSSMs still caused severe damage to all plants of these two Citrullus subspecies, in contrast with the $C$. colocynthis plants. The Cultivars Charleston Gray and Crimson Sweet had an intermediate TSSM infestation (Table 1). In an additional observation, these cultivars appeared to be susceptible to TSSM infestation in the greenhouse, in comparison with neighboring $C$. colocynthis plants.

PI346082 has been designated as C. lanatus var. citroides in the GRIN database (www. ars-grin.gov). However, it has morphological and DNA fingerprints of $C$. colocynthis (Levi et al., 2001b). Due to the limited number of seeds of this PI that could be germinated in our greenhouse, it could be used only in the limited free-choice bioassay with single leaves in a closed container. In this bioassay, the response ofTSSMs to PI 346082 was similar to the other C. colocynthis PIs (Table 2).

Citrullus colocynthis has the broadest geographical distribution among Citrullus species. It is found in East and North Africa, the Mediterranean region, and Central Asia. C. colocynthis also has wide genetic diversity (Levi et al., 2001a, 200b). However, the $C$. 
colcocynthis PIs do not have the desirable horticultural qualities of cultivated watermelon. Fruits of C. colocynthis are relatively small, globular, and bitter and contain compounds toxic to humans (Elawad et al., 1984; Goldfain etal., 1989) and insects(El-Naggar etal., 1989). Thus, it may be a challenge to incorporate insect resistance from $C$. colocynthis into cultivated watermelon without compromising fruit quality. Understanding the mechanism of insect resistance in $C$. colocynthis and identifying the genes conferring the resistance are essential before making any efforts to incorporate resistance into cultivated watermelon. Previous studies have shown an association of whitefly infestation with trichome density. Whiteflies may prefer low trichome density in some plant species (Butler and Henneberry, 1984), or high trichome density in others (Snyder et al., 1998). In a recent study examining resistance of Citrullus PIs to whiteflies there was no morphological distinction among trichomes of C. lanatus var lanatus, C. lanatus var. citroides and C. colocynthis. However, C. colocynthis had the highest trichome density among these species (Simmons and Levi, 2002). Additional experiments applying trichome exudates of the resistant $C$. colocynthis on leaves of susceptible watermelon cultivars might be useful to determine if trichomes play any role in TSSM resistance. Insect resistance in plants is a major tactic for controlling arthropod pests. However, to date, only a few breeding lines with insect resistance have been developed in cucurbits (Webb, 1998). Among them are three aphidresistant muskmelon breeding lines developed by McCreight et al. (1984), and a muskmelon cultivar containing resistance to melon aphid (Collins et al., 1994).

Our data supports the conclusion that among the tested plant germplasm, $C$. colocynthis was the least preferred by TSSM. Because of the smaller size of the mites, trichome density may be less of a factor than for whiteflies. Although no attempt was made to identify the mode of resistance, we suspect that the chemical properties of the plant sap of $C$. colocynthis may also play an important role in the observed resistance. Clearly a no-choice study should follow this one to determine if TSSM can survive and produce on the non-preferred $C$. colocynthis PIs. Still, the C. colocynthis PIs may be a useful source of resistance to spider mites and insect pests, and for improving TSSM resistance in cultivated watermelon. Our observations in the greenhouse revealed that where TSSMs do not have the pressure of their natural predators, they readily infest plants of all watermelon (C. lanatus var. lanatus) PIs or cultivars, but not the $C$. colocynthis plants. An F2 population(PI432337; C. colocynthis $\mathrm{X}$
PI 596669; C. lanatus var. citroides) has been constructed and will be used to determine the mode of inheritance of TSSM resistance.

\section{Literature Cited}

Burkill, H.M. 1985. The useful plants of west tropical Africa. vol. 1. 2nd ed. Royal Botanic Gardens, Kew, U.K.

Butler, G.D., Jr. and T.J. Henneberry. 1984. Bemisia tabaci: Effect of cotton leaf pubescence on abundance. Southw. Entomol. 9:91-94.

Collins, J.K., P. Perkins-Veazie, N. Maness, and B. Cartwright. 1994. Resistance in muskmelon cultivars to melon aphid. HortScience 29:1367.

Capinera, J.L. 2001. Handbook of vegetable pests. Academic Press, San Diego, Calif.

De Winter, B. 1990. A new species of Citrullus (Benincaseae) from the Namib desert, Namibia. Bothalia 20:209-211.

Elawad, A.A., E.M. Abdel Bari, O.M. Mahmoud, and S.E. Adam. 1984. The effect of Citrullus colocynthis on sheep. Vet. Hum. Toxicol. 6:481-485.

El-Naggar, M.E., M.M. Abdel-Sattar, and S.S. Mosallam. 1989. Toxicity of colocynithin and hydrated colocynithin from alcohol extract of Citrullus colocynthis pulp. J. Egypt. Soc. Parasitol. 1:179-185.

Food and Agricultural Organization. 1995. Production year book for 1994. No. 48. FAO United Nations, Rome.

Goldfain, D.A. Lavergne, A. Galian, L. Chauveinc, and F. Prudhomme. 1989. Peculiar acute toxic colitis after ingestion of colocynth: A clinicopathological study of three cases. Gut 30:1412-1418.

Hassan, S.A. and P.A. Oomen. 1985. Testing the side effects of pesticides on beneficial organisms by OILB working party, p. 145-152. In: N.W. Hussey and N. Scopes (eds.). Biological pest control: The glasshouse experience. Poole, Dorset, Blandford, U.K.

Huffaker, C.B., M. van de Vrie , and J.A. McMurtry. 1969. The ecology of tetranychid mites and their natural control. Annu. Rev. Entomol. 14:125-174.

Huffaker, C.B., M. van de Vrie, and J.A. McMurtry. 1970. Ecology of tetranychid mites and their natural enemies: Areview. II. Tetranychid populations and their possible control by predators: an evaluation. Hilgardia 40:391-458.

Jarret, R.L., L.C. Merrick, T. Holms, J. Evans, and M.K.Aradhya. 1997. Simple sequence repeats in watermelon [Citrullus lanatus (Thunb.) Matsum. \& Nakai]. Genome 40:433-441.

Jeppson, L.R., H.H. Keifer, and E.W. Baker. 1975. Mites injurious to economic plants, p. 614. Univ. Calif. Press, Berkeley.

Lazarre, M. and D. Gerling. 1993. The population dynamics of natural enemies of Bemisia tabaci in cotton fields and the influence of insecticide sprays. Phytoparasitica 21:171-172.

Levi, A., C.E. Thomas, A.P. Keinath, and T.C. Wehner. 2001a. Genetic diversity among watermelon (Citrullus lanatus and Citrullus colocynthis) accessions. Genet. Res. Crop Evolut. 48:559-566.
Levi, A., C.E. Thomas, T.C. Wehner, and X. Zhang. $2001 \mathrm{~b}$. Low genetic diversity indicates the need to broaden the genetic base of cultivated watermelon. Hortscience 36:1096-1101.

McCreight, J.D., A.N. Kishaba, and G.W. Bohn. 1984. AR Hale's Best Jumbo, AR5, and AR Topmark: Melon aphid resistant muskmelon breeding lines. HortScience 19:309-310.

McMurtry, J.A., C.B. Huffaker, and M. van de Vrie. 1970. Ecology of tetranychid mites and their natural enemies: A review. I. Tetranychid enemies: their biological characters and the impact of spray practices. Hilgardia 40:331-390.

Meeuse, A.D. 1962. The Cucurbitaceae of Southern Africa. Bothalia 8:1-111.

National Watermelon Promotion Board. 2004. www. watermelon.org.

Navot, N. and D. Zamir. 1987. Isozyme and seed protein phylogeny of the genus Citrullus $(\mathrm{Cu}-$ crbitaceae). Plant Syst. Evol. 156:61-67.

SAS Institute. 1994. SAS/STAT user's guide, version 6. 4th ed. SAS Inst., Cary, N.C.

Simmons, A.M. and D.M. Jackson. 2000. Evaluation of foliar-applied insecticides on abundance of parasitoids of Bemisia argentifolii (Homoptera: Aleyrodidae) in vegetables. J. Entomol. Sci. 35:1-8.

Simmons, A.M. and A. Levi. 2002. Sources of whitefly (Homoptera:Aleyredidne) resistance in Citrullus for the improvement of cultivated watermelon. HortScience 37:581-584.

Snyder, J.C.,A.M. Simmons, and R.R. Thacker. 1998. Attractancy and ovipositional response of adult Bemisia argentifolii (Homoptera: Aleyrodidae) to type IV trichome density on leaves of Lycopersicon hirsutum grown in three day-length regimes. J. Entomol. Sci. 33:270-281.

Thies, A.J. and A. Levi. 2004. resistance of watermelon germplasm to the peanut root-knot nematode. HortScience 38:1417-1421.

U.S. Department of Agriculture. 2004. Agricultural statistics. USDA Natl. Agr. Stat. Serv., Wash., D.C.

van de Vrie, M., J.A. McMurtry, and C.B. Huffaker. 1972. Ecology of tetranychid mites and their natural enemies: A review. III. Biology, ecology, and pest status, and host-plant relations of tetranychids. Hilgardia 41:343-432.

Watson, T.F. 1964. Influence of host plant condition on population increase of Tetranychus telarius (Linnaeus) (Acarina: Tetranychidae). Hilgardia 35:273-322.

Webb, S.E. 1998. Insect resistance in cucurbits: 1992-1998, p. 79-83. In: J.D. McCreight (ed.). Cucurbitaceae 98, Evaluation and enhancement of cucurbit germplasm. ASHS press, Alexandria, Va.

Whitaker, T.W. and G.N. Davis. 1962. Cucurbits botany, cultivation and utilization. Interscience Publ., Inc., New York.

Whitaker, T.W. and W.B. Bemis. 1976. Cucurbits, p. 64-69. In: N.W. Simmonds (ed.). Evolution of crop plants. Longman, London.

Zamir, D., N. Navot, and J. Rudich. 1984. Enzyme polymorphism in Citrullus lanatus and $C$. colocynthis in Israel and Sinai. Plant Syst. Evol. 146:163-167. 